\title{
The effects of 6 months of increased water intake on blood sodium, glomerular filtration rate, blood pressure, and quality of life in elderly (aged 55-75) men
}

Citation for published version (APA):

Spigt, M. G., Knottnerus, J. A., Westerterp, K. R., Olde Rikkert, M. G., \& van Schayck, C. P. (2006). The effects of 6 months of increased water intake on blood sodium, glomerular filtration rate, blood pressure, and quality of life in elderly (aged 55-75) men. Journal of the American Geriatrics Society, 54(3), 438-443. https://doi.org/10.1111/j.1532-5415.2005.00606.x

Document status and date:

Published: 01/01/2006

DOI:

10.1111/j.1532-5415.2005.00606.x

Document Version:

Publisher's PDF, also known as Version of record

\section{Document license:}

Taverne

\section{Please check the document version of this publication:}

- A submitted manuscript is the version of the article upon submission and before peer-review. There can be important differences between the submitted version and the official published version of record. People interested in the research are advised to contact the author for the final version of the publication, or visit the DOI to the publisher's website.

- The final author version and the galley proof are versions of the publication after peer review.

- The final published version features the final layout of the paper including the volume, issue and page numbers.

Link to publication

\footnotetext{
General rights rights.

- You may freely distribute the URL identifying the publication in the public portal. please follow below link for the End User Agreement:

www.umlib.nl/taverne-license

Take down policy

If you believe that this document breaches copyright please contact us at:

repository@maastrichtuniversity.nl

providing details and we will investigate your claim.
}

Copyright and moral rights for the publications made accessible in the public portal are retained by the authors and/or other copyright owners and it is a condition of accessing publications that users recognise and abide by the legal requirements associated with these

- Users may download and print one copy of any publication from the public portal for the purpose of private study or research.

- You may not further distribute the material or use it for any profit-making activity or commercial gain

If the publication is distributed under the terms of Article 25fa of the Dutch Copyright Act, indicated by the "Taverne" license above, 


\title{
The Effects of 6 Months of Increased Water Intake on Blood Sodium, Glomerular Filtration Rate, Blood Pressure, and Quality of Life in Elderly (Aged 55-75) Men
}

\author{
Mark G. Spigt, PhD, ${ }^{*} J$. A. Knottnerus, $M D, P h D,{ }^{*}$ Klaas R. Westerterp, PhD, ${ }^{\dagger}$ \\ Marcel G. M. Olde Rikkert, MD, PhD, ${ }^{\ddagger}$ and C. P. van Schayck, PhD*
}

OBJECTIVES: To study whether there are any negative or positive effects of 6 months of increased fluid intake in reasonably healthy elderly men.

DESIGN: Randomized trial.

SETTING: Community-based.

PARTICIPANTS: One hundred forty-one healthy participants aged 55 to 75 .

INTERVENTION: One group was given the advice to increase their daily fluid intake by $1.5 \mathrm{~L}$ of water; the other group was given placebo medication $(8 \mathrm{~mL}$ inactive syrup per day).

MEASUREMENTS: At 6 months blood sodium, glomerular filtration rate (GFR), blood pressure, and quality of life (QOL) were measured. The changes in water turnover were measured using deuterium.

RESULTS: Most subjects did not manage to increase their fluid intake by $1.5 \mathrm{~L}$. The average increase in the intervention group was approximately $1 \mathrm{~L}$. Twenty-four-hour water turnover in the water group was $359 \mathrm{~mL}$ (95\% confidence interval $=171-548)$ higher than that of the control group at 6-month follow-up. Blood pressure, sodium level, GFR, and QOL did not change significantly in either group during the intervention period. In addition, the cases reporting a worsening on the effect measures were equally distributed over the two study groups.

CONCLUSION: The advice to increase fluid intake by $1.5 \mathrm{~L}$ had no negative effects in reasonably healthy men aged 55 to 75. J Am Geriatr Soc 54:438-443, 2006.

Key words: dehydration; hyponatremia; blood pressure; water

From the *Department of General Practice, Research Institute Caphri, and ${ }^{\dagger}$ Department of Human Biology, Research Institute Nutrim, Maastricht University, Maastricht, the Netherlands; and ${ }^{\ddagger}$ Department of Geriatrics, University Medical Center, Nijmegen, the Netherlands.

This study was financed by the Netherlands Organization for Health Research and Development.

Address correspondence to Mark Spigt, Maastricht University, Department of General Practice, PO Box 616,6200 MD Maastricht, the Netherlands.

E-mail: m.spigt@hag.unimaas.nl

DOI: $10.1111 / \mathrm{j} .1532-5415.2005 .00606 . \mathrm{x}$
$\mathrm{D}$ ehydration is a common condition affecting older people, ${ }^{1}$ and it is assumed to be associated with comorbidity such as pressure ulcer, ${ }^{2}$ constipation, ${ }^{3}$ urolithiasis, ${ }^{4}$ headache, ${ }^{5}$ and even bladder, ${ }^{6}$ colorectal, ${ }^{7}$ and breast cancer. ${ }^{8}$ The chance of dehydration is increased in older people by reduced intracellular, extracellular, and totalbody water; ${ }^{9,10}$ a diminished sensation of thirst in response to a period of fluid restriction; and a reduction of the maximal water conservation capacity of the kidney. ${ }^{11}$

Alternatively, older people seem susceptible to overhydration. It is well documented that, on average, renal function declines with age due to glomerular sclerosis, which results in a decrease in cortical mass. ${ }^{12}$ As a consequence, mean glomerular filtration rate (GFR) declines. Additionally, there is less-efficient sodium-conserving capacity and a reduced ability to excrete a surplus water load because of decline in renal responsiveness to changes in concentration of antidiuretic hormone, natriuretic peptide, and aldosterone. ${ }^{13}$ It is assumed that these factors make older people prone to overhydration potentially leading to hyponatremia, which may be fatal in severe cases. ${ }^{14,15}$

In 2001, a study was started on the effects of increased urine output on bladder function and lower urinary tract symptoms (LUTS) in elderly men (55-75). The hypothesis behind this intervention is described elsewhere. ${ }^{16}$ In short, it was hypothesized that increasing urine output could trigger a physiological adaptive response of the bladder, leading to functional improvement of the bladder muscle, which might prevent frequently reported symptoms such as weak stream and incomplete emptying.

Because the increased urine output was achieved by increasing fluid intake by $1.5 \mathrm{~L}$, there was considerable debate whether this could do harm in such an elderly population. Searching the literature, it appeared that no longterm longitudinal data existed on the general health effects of increased fluid intake in older people.

It is not sound to base reluctance to hydrate in older people on theory and case reports, particularly if hydration potentially has positive health effects. Alternatively, it may well be that decreased renal and hemodynamic function 
make older people prone to overhydration, so that indeed one should be careful to give hydration advice to this population. ${ }^{17}$ To investigate whether increasing fluid intake has a relevant negative effect in older people, general health effects were monitored during this randomized trial. The effects on bladder function and LUTS are not part of this paper.

\section{METHODS}

The analysis of the general health effects of increased fluid intake in older people was part of a randomized trial in which the effects of increased fluid intake on bladder function and LUTS were investigated. In this trial, participants were randomized to advice to increase their daily fluid intake by $1.5 \mathrm{~L}$ of water or to placebo medication. Both groups were followed for 6 months.

\section{Description of the Trial}

The study population was recruited via 21 general practices. The general practitioners invited their total male population aged 55 to 75 to participate in the study. A screening questionnaire containing the International Prostate Symptom Score (IPSS; range $0-35$ ), ${ }^{18}$ questions on comorbidity, a drink diary, and informed consent documents were enclosed with the doctor's invitation. One thousand nine hundred eleven men who informed consent were screened for moderate LUTS (IPSS 8-19). The IPSS measures symptom severity of frequently reported LUTS, such as weak stream, hesitancy, and nocturia. Based on the screening questionnaire, 1,673 men were excluded. Exclusion criteria were mild or severe LUTS (IPSS $<8$ or $>19$ ), diabetes mellitus, Parkinson's disease, previous surgery of the lower urinary tract, a history of prostatic or bladder carcinoma, and the use of medication for LUTS or tricyclic antidepressive agents. In addition, potential participants were excluded who reported having a fluid intake of more than $2.0 \mathrm{~L}$ per day, who had a renal disease or used diuretics, in whom prostate cancer was diagnosed (prostate-specific antigen $>4.0$ and biopsy-confirmed carcinoma), or who had a blood sodium level less than $130 \mathrm{mmol} / \mathrm{L}$. One hundred forty-one participants were enrolled in the study.

A person who was otherwise not involved in the execution of the study and had no access to the baseline data generated a random allocation sequence using a computerized random-number generator and randomly assigned the participants to the two groups. People in the intervention group were advised to drink an additional three portions of $0.5 \mathrm{~L}$ of water spread over the day. To improve adherence to the intervention, they were supplied with 0.5 -L glasses. People in the control group received placebo medication $(8 \mathrm{~mL}$ inactive syrup per day). A person who was not involved in the effect measurements told the participants which intervention they would receive and kept contact with the participants during the study by telephone (at 2,8, and 18 weeks) to maintain treatment adherence.

The participants were informed that whether it was possible to prevent LUTS would be investigated. No information was given on the specific goal of either intervention to accomplish blinding for the nature of the interventions and the hypothesis of this study. It was mentioned that they would be allocated in a random fashion to one of the in- terventions and that it was possible that they received an ineffective intervention for a period of 6 months. All participants were fully informed after study termination. The ethical review board of the University Hospital Maastricht/ University of Maastricht approved the research protocol and the informed consent procedure.

\section{Measurements}

\section{Assessment of Total Body Water and Water Turnover}

To measure the hydration status of the participants before and during the study period and to measure the actual change in water turnover, the deuterium-labeled water method was used. This is regarded as the criterion standard for measuring total body water (TBW) and water turnover in humans. ${ }^{19,20}$ After equilibration of a known mass of deuterium in the body water compartment, TBW can be calculated by measuring deuterium concentration in urine. Subsequently, deuterium is eliminated depending on the rate of water turnover; the more fluid people consume, the lower the deuterium concentration in urine after a certain period of time. Accordingly, urine samples from both groups, taken at different points within 2 weeks (Days 0,1 , 7 , and 14), were analyzed. This was done before the baseline assessment in the hospital and in the final 2 weeks of the intervention period. Therefore, if participants complied fully with the intervention, their water turnover would increase by $1.5 \mathrm{~L}$ from their baseline level.

\section{Assessment of (Adverse) Effects}

If a hydration regime has negative effects on the general health of older people, it is primarily expected to result in changes in blood sodium levels, renal function, hemodynamic function, and (global) quality of life. The effects of the intervention were assessed at baseline and at the end of the intervention period (at 6 months). From blood samples, sodium and creatinine levels were determined. From creatinine levels, GFR was estimated using the Cockroft and Gault formula. ${ }^{21}$ (For men, GFR $=((140$-age $) \times$ weight $) /$ (serum creatinine $\times 72$.) (Serum creatinine is in $\mathrm{mg} / \mathrm{dL}$, to convert $\mu \mathrm{mol} / \mathrm{L}$ to $\mathrm{mg} / \mathrm{dL}$ divide by 88.4.) Diastolic and systolic blood pressure (BP) were measured two times at each assessment using the oscillometric device Omron 705CP (OMRON Matsusaka Co. Ltd., Matsusaka City, Mie-Ken, Japan). ${ }^{22}$ The mean of the two measurements was calculated. The Medical Outcomes Study 36-item short form (SF36) was used to monitor (global) quality of life (QOL). ${ }^{23}$ The mean score of the different SF36 subscales was included in the analysis.

\section{Statistical Analysis}

It was discovered later that three subjects had a baseline IPSS score above the maximum of 19 points (scores of 20, 21 , and 22, respectively). They were allocated in error, but because this criterion was not essential for the research question, they were not excluded from the statistical analysis.

The baseline differences between the two age subgroups (55-65 and 66-75) were analyzed using independent-sample $t$ test. The linear relationship between age and baseline characteristics was analyzed using linear regression. For the estimation of the treatment effect, multiple 
linear regression analyses (analysis of covariance) were performed in which the follow-up measurement was used as the outcome variable, the intervention type as a predictive variable, and the baseline score of that outcome variable and age as covariates. ${ }^{24}$ As a per-protocol analysis, the analysis was subsequently performed without the subjects in the experimental intervention group, who had not increased their water turnover above the median (intervention group) level. In addition, the linear relationship between the effect measures and actual increase in water turnover (linear regression) was studied. The possible harmful effects of increased water intake were further investigated by selecting the worst $20 \%$ of cases on each effect parameter, after which the distribution of these cases between the water and control group was analyzed. As an exploratory analysis, possible effect modification of age and GFR was analyzed by performing a stratified analysis of treatment effect for these subgroups. The analysis was performed in SPSS (SPSS Inc., Chicago, IL). Ninety-five percent confidence intervals (CIs) were determined, and a twotailed $P$-value $<.05$ was considered statistically significant.

\section{RESULTS}

\section{Baseline Characteristics}

At baseline, the elderly subgroup (66-75) had a statistically significantly lower 24-hour water turnover than the younger subgroup (55-65) (Table 1). GFR and blood sodium level were also statistically significantly lower in the older subjects. Age was statistically significantly related to a decrease in TBW, 24-hour water turnover, and GFR. Systolic BP was statistically significantly greater with older age.

\section{Effects of Increased Fluid Intake}

Table 2 shows the effects of increased fluid intake. If participants in the experimental group had complied perfectly with the intervention, their water turnover would have increased by $1.5 \mathrm{~L}$, but most subjects did not increase their fluid intake by $1.5 \mathrm{~L}$, as is shown by the average increase of
1.0 L. Twenty-four-hour water turnover in the water group was $359 \mathrm{~mL}$ higher than in the control group at 6-month follow-up.

TBW, BP, blood sodium level, serum creatinine level, GFR, and QOL remained constant in both groups during the intervention period. Excluding the nonadherent participants from the water group (24-hour water turnover increase less than the median of $955 \mathrm{~mL}$ ) from the analysis did not influence the results significantly (data not shown).

In addition, there was no statistically significant relationship between changes in water turnover and changes in effect (coefficients for 1-L increase in water turnover (mean \pm standard error): diastolic $\mathrm{BP}=0.8 \pm 1.4 \mathrm{mmHg}$, systolic $\mathrm{BP}=5 \pm 3 \mathrm{mmHg}$, creatinine $=1.3 \pm 1.7 \mu \mathrm{mol} / \mathrm{L}$, $\mathrm{GFR}=-1.7 \pm 1.6 \mathrm{~mL} / \mathrm{min}$, sodium $=-0.7 \pm 0.4 \mathrm{mmol} /$ $\mathrm{L}, \mathrm{SF} 36$ score $=3 \pm 2$ ).

\section{Distribution of Worst Cases}

The cases reporting a relatively large worsening on the effect measures were equally distributed over the two study groups (Table 3), and a blood sodium level less than $130 \mathrm{mmol} / \mathrm{L}$ did not occur during the study period.

\section{Effect Modification by Age and GFR}

The stratified analyses for age revealed that the effects of increased water intake were not different for the elderly subgroup (66-75) than for the younger subgroup (55-65) (data not shown).

Stratification on GFR ( $<$ or $\geq 80 \mathrm{~mL} / \mathrm{min}$ ) appeared to modify the effect of increased water intake but only on BP. Diastolic and systolic BP decreased significantly in men in the intervention group with a GFR lower than $80 \mathrm{~mL} / \mathrm{min}$. At 6 months, the effect of water was determined to be $-5.6 \mathrm{mmHg} \quad(P=.002, \quad 95 \% \quad$ confidence interval $(\mathrm{CI})=-9.1$ to -2.1 ) for diastolic $\mathrm{BP}$ and $-8.6 \mathrm{mmHg}$ $(P=.03,95 \% \mathrm{CI}=-16.3$ to -0.9$)$ for systolic BP. The data appeared consistent, because, in a subgroup with high (baseline) BP and low GFR, the size of the effect increased,

Table 1. Baseline Characteristics for Different Age Groups, the Differences Between These Groups and the Estimated Effect of Age

\begin{tabular}{|c|c|c|c|c|}
\hline \multirow[b]{3}{*}{ Characteristic } & \multicolumn{2}{|c|}{ Age } & \multirow{3}{*}{$\begin{array}{l}\text { Difference } \\
\text { Between } \\
\text { Means (SE) }\end{array}$} & \multirow{3}{*}{$\begin{array}{c}\text { Estimated } \\
\text { Effect of } 1-\text { Year } \\
\text { Increase in Age (SE)* }\end{array}$} \\
\hline & $55-65(n=89)$ & $66-75(n=52)$ & & \\
\hline & \multicolumn{2}{|c|}{ Mean \pm Standard Deviation } & & \\
\hline 24-hour water turnover, $\mathrm{mL}$ & $3,075 \pm 592$ & $2,858 \pm 509$ & $-217(103)^{\dagger}$ & $-30(9)^{\dagger}$ \\
\hline Total body water, L & $43 \pm 5$ & $42 \pm 5$ & $-1.5(0.8)$ & $-0.3(0.1)^{\dagger}$ \\
\hline Diastolic blood pressure, $\mathrm{mmHg}$ & $93 \pm 11$ & $91 \pm 12$ & $-1(2)$ & $0.04(0.2)$ \\
\hline Systolic blood pressure, $\mathrm{mmHg}$ & $158 \pm 22$ & $169 \pm 22$ & $5(4)$ & $1.0(0.4)^{\dagger}$ \\
\hline Serum creatinine, $\mu \mathrm{mol} / \mathrm{L}$ & $91 \pm 14$ & $91 \pm 13$ & $0.5(2.3)$ & $-0.09(0.2)$ \\
\hline Glomerular filtration rate, $\mathrm{mL} / \mathrm{min}$ & $87 \pm 16$ & $77 \pm 14$ & $-10(3)^{\dagger}$ & $-1.3(0.3)^{\dagger}$ \\
\hline Blood sodium, mmol/L & $138 \pm 3$ & $137 \pm 3$ & $-1.1(0.5)^{\dagger}$ & $-0.09(0.05)$ \\
\hline Quality of life & $73 \pm 16$ & $77 \pm 12$ & $5(3)$ & $0.4(0.3)$ \\
\hline
\end{tabular}

* The estimated effect was determined using regression analysis.

${ }^{\dagger} P<.05$.

${ }^{\ddagger}$ Medical Outcomes Study 36-item Short Form score.

$\mathrm{SE}=$ standard error. 
Table 2. The Effects of Increased Water Intake

\begin{tabular}{|c|c|c|c|}
\hline \multirow[b]{2}{*}{ Outcome Parameters } & $\begin{array}{c}\text { Water } \\
(n=70)\end{array}$ & $\begin{array}{l}\text { Control } \\
(n=71)\end{array}$ & \multirow[b]{2}{*}{$\begin{array}{l}\text { Estimated Effect of Water } \\
\text { (95\% Confidence Interval)* }\end{array}$} \\
\hline & \multicolumn{2}{|c|}{$\begin{array}{l}\text { Mean } \pm \text { Standard } \\
\text { Deviation }\end{array}$} & \\
\hline \multicolumn{4}{|l|}{ 24-hour water turnover, mL } \\
\hline Baseline & $3,034 \pm 631$ & $2,950 \pm 498$ & \\
\hline Six months & $4,036 \pm 988$ & $3,628 \pm 764$ & $359(171-548)^{\dagger}$ \\
\hline \multicolumn{4}{|l|}{ Total body water, $\mathrm{L}$} \\
\hline Baseline & $42 \pm 4$ & $43 \pm 5$ & \\
\hline Six months & $42 \pm 4$ & $43 \pm 5$ & $0.2(-0.4-0.8)$ \\
\hline \multicolumn{4}{|c|}{ Diastolic blood pressure, $\mathrm{mmHg}$} \\
\hline Baseline & $92 \pm 11$ & $92 \pm 11$ & \\
\hline Six months & $89 \pm 12$ & $90 \pm 11$ & $-0.9(-3.7-2.0)$ \\
\hline \multicolumn{4}{|c|}{ Systolic blood pressure, $\mathrm{mmHg}$} \\
\hline Baseline & $166 \pm 22$ & $165 \pm 23$ & \\
\hline Six months & $159 \pm 25$ & $161 \pm 24$ & $-2.4(-8.0-3.2)$ \\
\hline \multicolumn{4}{|l|}{ Serum creatinine, $\mu \mathrm{mol} / \mathrm{L}$} \\
\hline Baseline & $91 \pm 12$ & $91 \pm 14$ & \\
\hline Six months & $91 \pm 12$ & $92 \pm 16$ & $-1.5(-4.8-1.9)$ \\
\hline \multicolumn{4}{|c|}{ Glomerular filtration rate, $\mathrm{mL} / \mathrm{min}$} \\
\hline Baseline & $82 \pm 16$ & $85 \pm 16$ & \\
\hline Six months & $81 \pm 16$ & $85 \pm 19$ & $-0.1(-3.2-2.9)$ \\
\hline \multicolumn{4}{|l|}{ Blood sodium, mmol/L } \\
\hline Baseline & $137 \pm 3$ & $138 \pm 3$ & \\
\hline Six months & $138 \pm 3$ & $138 \pm 3$ & $-0.2(-1.1-0.6)$ \\
\hline \multicolumn{4}{|l|}{ Quality of life } \\
\hline Baseline & $74 \pm 14$ & $74 \pm 15$ & \\
\hline Six months & $74 \pm 14$ & $73 \pm 15$ & $1.1(-2.4-4.8)$ \\
\hline
\end{tabular}

* The estimated effect was determined using regression analysis, in which differences in baseline score and age were adjusted for.

${ }^{\dagger} P<.05$.

${ }^{\ddagger}$ Medical Outcomes Study 36-item Short Form score.

and the effect remained statistically significant even in this small subgroup (diastolic $\mathrm{BP}=-7 \mathrm{mmHg}, P=.03,95 \%$ $\mathrm{CI}=-13$ to -1 ; systolic $\mathrm{BP}=-18 \mathrm{mmHg}, P=.005$, $95 \% \mathrm{CI}=-30$ to -6$)$.

Table 3. Distribution of Selected Adverse Effects Between the Two Study Groups

\begin{tabular}{|c|c|c|}
\hline & $\begin{array}{l}\text { Water } \\
(n=70)\end{array}$ & $\begin{array}{l}\text { Control } \\
(\mathrm{n}=71)\end{array}$ \\
\hline Worst $20 \%$ & \multicolumn{2}{|c|}{ n (\%) } \\
\hline $\begin{array}{l}\text { Diastolic blood pressure } \\
\text { (>4 mmHg increase) }\end{array}$ & $14(21)$ & $15(22)$ \\
\hline $\begin{array}{l}\text { Systolic blood pressure } \\
\text { (>6 mmHg increase) }\end{array}$ & $15(23)$ & $14(21)$ \\
\hline $\begin{array}{l}\text { Serum creatinine ( }>6 \mu \mathrm{mol} / \mathrm{L} \\
\text { increase) }\end{array}$ & $15(22)$ & $14(20)$ \\
\hline $\begin{array}{l}\text { Glomerular filtration rate } \\
\text { (>6.00 } \mathrm{mL} / \mathrm{min} \text { decrease })\end{array}$ & $13(21)$ & $12(18)$ \\
\hline $\begin{array}{l}\text { Quality of life (>7.36-point } \\
\text { decrease)* }\end{array}$ & $9(15)$ & $15(23)$ \\
\hline
\end{tabular}

Note: There were no statistically significant differences between the two study groups.

${ }^{*}$ Medical Outcomes Study 36-item Short Form score.

\section{DISCUSSION}

Negative and positive effects of hydration are often presumed, but surprisingly little scientific evidence exists on the long-term effects of hydration, especially in the "average" elderly individual. This study provided a unique opportunity to study the general health effects and potential adverse effects of hydration in older people.

At baseline, there was a statistically significant negative relationship between age and TBW and between age and 24-hour water turnover. Others have reported the observed decrease in TBW with increasing age, which is assumed to be largely determined by a decrease in fat free mass. ${ }^{25} \mathrm{~A}$ decrease in water turnover with increasing age confirms the findings of a previous study. ${ }^{25}$ Several factors, such as a reduced physical activity level ${ }^{26}$ and reduced beverage intake, ${ }^{11,25}$ might explain the lower water turnover in older people. Whether reduced water turnover has any causal relationship with other age-related negative changes in the human body is unknown. It is also unknown whether influencing these factors by increasing fluid intake has a positive effect.

The advice to increase fluid intake by $1.5 \mathrm{~L}$ had no negative effects in this study. Neither were there differences in the distribution of adverse events between the control and experimental groups. In addition, in the long term, the 
older subgroup (65-75) was found to be as able to cope with the increased water intake as the younger individuals (55-65). Therefore, the advice to increase fluid intake by $1.5 \mathrm{~L}$ can be safely given to reasonably healthy elderly men aged 55 to 75 . Safety is not guaranteed in patients with known renal disorders, with a blood sodium level less than $130 \mathrm{mmol} / \mathrm{L}$, with a high (self-reported) prior fluid intake, or with evident cardiac decompensation, because they were not included in this study. In such a population, extra precautionary measures should be taken to monitor possible overhydration. In addition, too-large increases in water intake (e.g., 5-10 L/d) will probably be harmful, especially in an elderly population and in cases of malnutrition. Furthermore, because this study addressed men with possible prostatic-related LUTS, no elderly women were included. This limits the generalizability of the results to the female population. On average, women have less TBW than man. Therefore, the same amount of consumed fluid will lead to larger relative changes in hydration. This may make them more vulnerable to overhydration.

Whether beneficial effects are to be expected of increased fluid intake remains poorly investigated. Some authors state that older people are susceptible to dehydration and claim significant morbidity due to reduced water intake. ${ }^{2,27}$ Others have raised doubts about the need for extra hydration. For instance, one study ${ }^{17}$ concluded that there is no reason to encourage elderly people to drink more fluids. In a large cohort study, they observed few differences in general health measures between people with high self-reported fluid intakes and those with low fluid intake. The current study examined the safety of increasing the fluid intake in elderly men. Because no harmful effects were observed, doctors can decide for themselves whether to recommend increased fluid intake to prevent, for example, constipation. As regards future research on this topic, it is important that potential positive and negative effects be studied in randomized rather than observational studies. This way, confounders and unblinded evaluations are not likely to bias the observations and following recommendations.

One topic that needs further investigation is the effect of increased fluid intake on diastolic and systolic BP. In this study, beneficial effects were observed in a subgroup of persons with low GFR. Some research has been performed on the short-term effects of increased fluid intake on BP. This research has shown that BP increases temporarily as a result of increased fluid intake. ${ }^{28}$ In addition, the relationship between decreased renal function and high BP is known, ${ }^{29}$ although as far as the authors know, a possible positive effect of long-term increased fluid intake on hypertension has not been addressed before. It was hypothesized that a different physiological adaptation to overhydration subsequently leading to decreased peripheral resistance mediated the decline in BP in subjects with decreased renal function. Some caution is required, because this observation is based on subgroup analyses. Future studies in clinically relevant populations (patients with hypertension and low GFR) are needed to verify these results and to investigate the underlying physiological mechanism.

Finally, increasing fluid intake and achieving a large contrast between study groups is difficult. In this study, a mean contrast of approximately $350 \mathrm{~mL}$ per 24 hours was achieved, which was lower than the 1.5 liters that the intervention group had been requested to increase their intake by. Poor blinding and contamination are risks, because water is impossible to copy into a placebo, and any subject hearing of promising new advice could easily implement this in his daily life. This was solved by using an unusual design in which a placebo control group and partial informed consent were used (informed about the content but not the idea behind the interventions). Because the control group was blind to the rationale of drinking more water and had their own intervention (syrup), it was assumed that the extremely hot summer of 2003 caused the increase in water turnover in the placebo group. The mean ambient temperature during the follow up measurements was $20.9^{\circ} \mathrm{C}$ (range $17.3-24.6^{\circ} \mathrm{C}$ ), whereas $17.6^{\circ} \mathrm{C}$ is normal for that period. Consequently, the control group had a much higher fluid intake than at baseline, reducing the contrast between the two groups. The issue of blinding and possible contamination has been discussed at length elsewhere. ${ }^{30}$

\section{CONCLUSION}

The advice to increase fluid intake by $1.5 \mathrm{~L}$ had no negative long-term effects on hemodynamic outcome measures or on quality of life in reasonably healthy men aged 55 to 75 . Future studies should further investigate the relationship between age, age-related physiological changes, and decreased water turnover. In addition, potential positive effects, on, for example, BP in patients with decreased GFR, should be studied more carefully.

\section{ACKNOWLEDGMENTS}

Financial Disclosure: This study was financed by the Netherlands Organization for Health Research and Development (ZonMw: www.zonmw.nl). This organization is a governmental organization without a conflict of interest.

Author Contributions: Spigt: principal investigator of the trial, responsible for acquisition of subjects and data, data analysis and interpretation, preparation of the manuscript. Knottnerus: added family medicine and epidemiological expertise to the project, member of the project team leading the trial, data analysis and interpretation, preparation of the manuscript. Westerterp: involved in the deuterium analyses, data analysis and interpretation, preparation of the manuscript. Olde Rikkert: added gerontology expertise to the project, preparation of the manuscript. Van Schayck: added preventive medicine and epidemiological expertise to the project, member of the project team leading the trial, data analysis and interpretation, preparation of the manuscript.

Sponsor's Role: We proposed the trial to ZonMw, and after that, the sponsor had no say in the conduct of the trial or in the preparation of the manuscript.

\section{REFERENCES}

1. Weinberg AD, Minaker KL. Dehydration. Evaluation and management in older adults. Council on Scientific Affairs, American Medical Association. JAMA 1995;274:1552-1556.

2. Casimiro C, Garcia de Lorenzo A, Usan L. Prevalence of decubitus ulcer and associated risk factors in an institutionalized Spanish elderly population. Nutrition 2002;18:408-414.

3. Arnaud MJ. Mild dehydration. A risk factor of constipation? Eur J Clin Nutr 2003;57(Suppl 2):S88-S95. 
4. Borghi L, Meschi T, Amato F et al. Urinary volume, water and recurrences in idiopathic calcium nephrolithiasis: A 5-year randomized prospective study. J Urol 1996;155:839-843.

5. Blau JN, Kell CA, Sperling JM. Water-deprivation headache: A new headache with two variants. Headache 2004;44:79-83.

6. Michaud DS, Spiegelman D, Clinton SK et al. Fluid intake and the risk of bladder cancer in men. N Engl J Med 1999;340:1390-1397.

7. Tang R, Wang JY, Lo SK et al. Physical activity, water intake and risk of colorectal cancer in Taiwan: A hospital-based case-control study. Int J Cancer 1999;82:484-489.

8. Bar David Y, Gesundheit B, Urkin J et al. Water intake and cancer prevention. J Clin Oncol 2004;22:383-385.

9. Ritz P. Chronic cellular dehydration in the aged patient. J Gerontol A Biol Sci Med Sci 2001;56A:M349-M352.

10. Olde Rikkert MG, Deurenberg P, Jansen RW et al. Validation of multifrequency bioelectrical impedance analysis in monitoring fluid balance in healthy elderly subjects. J Gerontol A Biol Sci Med Sci 1997;52A:M137-M141.

11. Kenney WL, Chiu P. Influence of age on thirst and fluid intake. Med Sci Sports Exerc 2001;33:1524-1532.

12. Epstein M. Aging and the kidney. J Am Soc Nephrol 1996;7:1106-1122.

13. Beck LH. The aging kidney. Defending a delicate balance of fluid and electrolytes. Geriatrics 2000;55:26-28, 31-32.

14. Goldman MB. Moderate hyponatremia and death in a polydipsic schizophrenic on lithium. Biol Psychiatry 1994;36:485-486.

15. Fox BD. Crash diet potomania. Lancet 2002;359:942.

16. Spigt MG, van Schayck CP, van Kerrebroeck PE et al. Pathophysiological aspects of bladder dysfunction: A new hypothesis for the prevention of 'prostatic' symptoms. Med Hypotheses 2004;62:448-452.

17. Lindeman RD, Romero LJ, Liang $\mathrm{HC}$ et al. Do elderly persons need to be encouraged to drink more fluids? J Gerontol A Biol Sci Med Sci 2000;55A: M361-M365.

18. Barry MJ, Fowler FJ Jr, O'Leary MP et al. The American Urological Association symptom index for benign prostatic hyperplasia The Measurement
Committee of the American Urological Association. J Urol 1992;148:1549_ 1557.

19. Westerterp KR, Wouters L, van Marken Lichtenbelt WD. The Maastricht protocol for the measurement of body composition and energy expenditure with labeled water. Obes Res 1995;3(Suppl 1):49-57.

20. Westerterp KR. Body composition, water turnover and energy turnover assessment with labelled water. Proc Nutr Soc 1999;58:945-951.

21. Cockcroft DW, Gault MH. Prediction of creatinine clearance from serum creatinine. Nephron 1976;16:31-41.

22. O'Brien E, Atkins N, Mee F et al. A new audiovisual technique for recording blood pressure in research: The Sphygmocorder. J Hypertens 1995;13:1734-1737.

23. Aaronson NK, Muller M, Cohen PD et al. Translation, validation, and norming of the Dutch language version of the SF-36 Health Survey in community and chronic disease populations. J Clin Epidemiol 1998;51:1055-1068.

24. Twisk J, Proper K. Evaluation of the results of a randomized controlled trial. How to define changes between baseline and follow-up. J Clin Epidemiol 2004;57:223-228.

25. Raman A, Schoeller DA, Subar AF et al. Water turnover in 458 American adults 40-79 yr of age. Am J Physiol Ren Physiol 2004;286:F394-F401.

26. Shimamoto H, Komiya S. Comparison of body water turnover in endurance runners and age-matched sedentary men. J Physiol Anthropol Appl Human Sci 2003;22:311-315

27. Mukand JA, Cai C, Zielinski A et al. The effects of dehydration on rehabilitation outcomes of elderly orthopedic patients. Arch Phys Med Rehabil 2003;84:58-61.

28. Lu CC, Diedrich A, Tung CS et al. Water ingestion as prophylaxis against syncope. Circulation 2003;108:2660-2665.

29. Culleton BF, Larson MG, Wilson PW et al. Cardiovascular disease and mortality in a community-based cohort with mild renal insufficiency. Kidney Int 1999;56:2214-2219.

30. Spigt MG, Knipschild P, van Schayck CP et al. The validity and ethics of giving placebo in a randomized nonpharmacologic trial was evaluated. J Clin Epidemiol 2005;58:350-356. 